\title{
A study on demand analysis of farm machineries and equipments in Nilgiris district
}

\section{T. Samsai, S. Praveena and S. Kowshika}

Received : 05.12.2017; Revised : 10.03.2018; Accepted : 24.03.2018

\begin{abstract}
This study was undertaken with an overall objective of assessing the demand for farm machineries and equipments in Nilgiris district of Tamil Nadu. A total of 180 farmers were selected from the different taluks of Nilgiris for the study. Both primary and secondary data were collected and utilized for the study. Majority of the sample respondents were middle aged, educated and experienced in farming. Majority of the sample farmers did not own any farm machineries and aware on farm machineries and equipments through Government institutions. The utilization of farm machineries and equipments for cole crops and plantation crops were found that it was used for various field operations like, field preparation, earthing up and weeding, plant protection, irrigation and harvesting. Tractors and power tillers were mostly used for land preparation by the sample farmers. The sample dealers were middle aged, had better educational status and well experienced in retailing. All the sample dealers were sole proprietors and deal with products like seeds, fertilizers, farm equipments and pesticides. Methods of promotion followed by the sample farmers were mainly by using phamplets, field demonstrations, stalls and exhibitions. Farmer's preference and brand image were the major factors influencing the brand preference of the sample dealers.
\end{abstract}

KEY WORDS : Farm machineries, Farm mechanization, Farm equipments, Probit

How to cite this paper : Samsai, T., Praveena, S. and Kowshika, S. (2018). A study on demand analysis of farm machineries and equipments in Nilgiris district. Internat. J. Com. \& Bus. Manage, 11(1) : 59-68, DOI: 10.15740/HAS/IJCBM/11.1/59-68.

\section{MEMBERS OF THE RESEARCH FORUM}

Correspondence to:

T. Samsai, Department of Agricultural and Rural Management, Tamil Nadu Agricultural University, Coimbatore (T.N.) India

Authors' affiliations:

S. Praveena and S. Kowshika, Department of Agricultural and Rural Management, Tamil Nadu Agricultural University, Coimbatore (T.N.) India 